\title{
Performance and economic viability of protein supplementation for grazing cattle steers in the wet and dry-wet transition season
}

\section{Desempenho e viabilidade econômica da suplementação proteica de novilhos de corte em pasto no período das águas e transição águas-seca}

\author{
Wolney Alvim Pereira Junior ${ }^{1 *}$; Mario Fonseca Paulino²; \\ Joanis Tilemahos Zervoudakis 3 ; Pedro Veiga Rodrigues Paulino ${ }^{3}$; \\ Renata Pereira da Silva-Marques ${ }^{4}$; Antônio José Neto ${ }^{5}$; Dagberto França $a^{6}$; \\ Luciana Keiko Hatamoto-Zervoudakis ${ }^{3}$
}

\begin{abstract}
The objective was to evaluate performance and economic viability of protein supplementation of grazing beef cattle in the wet and dry-wet transition season. Eighty non-castrated Nellore steers, body weight of $371 \pm 11.3 \mathrm{~kg}$ were used in the experiment. The treatments were the following: SM - Mineral supplement; Protein mineral supplements (SMP 20\% FS - soybean meal: $410 \mathrm{~g} / \mathrm{animal}$; SMP 40\% UR - urea: $223 \mathrm{~g} / \mathrm{animal}$; and SMP 40\% UP - protect urea: $236 \mathrm{~g} / \mathrm{animal})$. It was used a complete random design with 20 replicates per treatment. There was a difference in the results $(\mathrm{P}<0.05)$ of PMS $40 \% \mathrm{UP}$ compared with SM, with average daily gain (ADG) of $1.06 \mathrm{~kg}$ /animal for SMP $40 \%$ UP and $0.95 \mathrm{~kg} /$ animal for $\mathrm{SM}$, respectively. There was difference $(\mathrm{P}<0.10)$ in the fat accumulation rate in longissimus dorsi muscle (Tx.EGLD) between treatments. The PMS 40\% UP supplement showed an accumulation of fat $0.018 \mathrm{~mm} /$ day while the SMP $40 \%$ UR had a lower rate of fat $0.011 \mathrm{~mm} /$ day. There was no effect $(\mathrm{P}>0.10)$ of treatments on the rate of accumulation of fat in the rump region. All treatments presented a positive net margin. The best net margin was observed for treatment PMS $40 \%$ UP, that is, R $\$ 123.92$ per animal/period, whereas the smallest was observed in treatment PMS $20 \% \mathrm{FS}$, that is, R $\$ 98.91$ per animal/period. Protein supplementation with a source of protected nitrogen can be used as a strategy to increase the performance of beef cattle on pasture of Brachiaria brizantha cv. Xaraés during the wet and dry-wet transition.
\end{abstract}

Key words: Beef cattle, cost of production, weight gain, supplement, ultrasonography

\section{Resumo}

Objetivou avaliar o desempenho e viabilidade econômica da suplementação proteica de bovinos de corte em pasto no período das águas e transição águas-seca. Foram utilizados 80 novilhos Nelore, não castrados, peso corporal médio de $371 \pm 11,3 \mathrm{~kg}$. Os tratamentos foram: SM - Suplemento Mineral;

\footnotetext{
${ }^{1}$ M.e em Nutrição de Ruminantes, Universidade Federal de Viçosa, UFV, Viçosa, MG, Brasil. E-mail: wolneyzt@hotmail.com

2 Prof. Dr., UFV, Viçosa, MG, Brasil. E-mail: mpaulino@ufv.br

${ }^{3}$ Profs. Drs., Universidade Federal de Mato Grosso, UFMT, Cuiabá, MT, Brasil. E-mail: joanis@ufmt.br; pedro_veiga@cargill. com; lukeiko@yahoo.com.br

${ }^{4}$ Discente de Doutorado em Ciência Animal, UFMT, Cuiabá, MT, Brasil. E-mail: renatinharps@hotmail.com

${ }^{5}$ Discente de Doutorado em Zootecnia, Universidade Estadual Paulista, UNESP, Jaboticabal, SP, Brasil. E-mail: antoniojoseneto@ yahoo.com.br

${ }^{6}$ Médico Veterinário, Universidade do Oeste Paulista, UNOESTE, Presidente Prudente, SP, Brasil. E-mail: dago.franca@gmail. com

* Author for correspondence
} 
Suplementos mineral proteico (SMP 20\% FS -farelo soja: 410 g/animal; SMP 40\% UR-ureia: 223 g/animal; e SMP 40\% UP-ureia protegida: $236 \mathrm{~g} /$ animal. O delineamento utilizado foi inteiramente casualizado com 20 repetições por tratamento. Houve diferença nos resultados $(\mathrm{P}<0,05)$ do SMP $40 \%$ UP, comparado com o SM, com ganho médio diário (GMD) de 1,06 kg/animal para SMP 40\% UP e 0,95 $\mathrm{kg} /$ animal para SM. Houve diferença $(\mathrm{P}<0,10)$ na taxa de acúmulo de gordura no músculo Longissimus dorsi (Tx.EGLD) entre os tratamentos, sendo que o suplemento SMP $40 \%$ UP apresentou um acúmulo de $0,018 \mathrm{~mm}$ de gordura/dia, enquanto o SMP $40 \%$ UR teve uma taxa inferior de $0,011 \mathrm{~mm}$ de gordura/ dia). Não houve efeito $(\mathrm{P}>0,10)$ dos tratamentos sobre a taxa de acúmulo de gordura na região da garupa. Todos os tratamentos apresentaram margem líquida positiva. A melhor margem líquida foi observada no tratamento SMP 40\% UP, ou seja, R $\$ 123,92$ por animal/período, enquanto a menor, no tratamento SMP $20 \%$ FS, ou seja, R $\$ 98,91$ por animal/período. A suplementação proteica com uma fonte de nitrogênio protegido pode ser utilizada como uma ferramenta para aumentar o desempenho de bovinos de corte sob pastejo de Brachiaria brizantha cv. Xaraés no período das águas e transição águas-seca.

Palavras-chave: Bovinos de corte, custo de produção, ganho de peso, suplemento, ultrassonografia

\section{Introduction}

The beef production system in Brazil is strongly grounded in production on pasture, which favors low livestock production costs compared to most other countries, since the pasture is universally considered the primary and most economical source of nutrients for cattle (PAULINO, 1998). This scenario highlights the importance and responsibility of the Brazilian cattle sector in the world economy, as it has great potential to produce beef for the world.

The nutritional value of forage and carrying capacity of pastures are key to maximize animal productivity. Deficiencies of nutrients in tropical fodder are common and attempting to balance these nutrients with supplementation contributes to maintaining a standard of uniform fermentation, constant rumen fermentation and, consequently, increased availability of energy substrates (volatile fatty acids) and microbial protein (COSTA et at., 2011; PAULINO et al., 2002). However, these biological assumptions should be linked to the condition that the adoption of supplementation within the production system meets a favorable cost-benefit ratio.

Microbial protein synthesized in the rumen varies with the energy available for microorganisms and the degraded nitrogen compounds in the rumen, be it in the form of ammonia, amino acids or peptides. When the supply originating from ingested or endogenous recycling material does not meet the microbial requirements, there are limitations of microbial growth (SNIFFEN et al., 1992) and digestion depression of the cell wall, resulting in decreased intake. For Van Soest (1994), intake depression can be attributed to nitrogen deficiency for the animal, reduction in rumen fermentation or lower output of rumen undigested waste.

Different sources of nitrogen used in the supplementation of grazing animals in tropical areas may provide different answers in animal performance, which can be explained by the organic matter digestibility of forage, the nitrogen recycling potential and its effect on the nitrogen pool, and the contribution of protein supplementation on the animals' energy state in the medium and long terms (KNORR et al., 2005; KÖSTER et al., 1996; BANDYK et al., 2001).

According to Santos (2006), the nitrogen sources used in animal feed can be classified into: non-protein nitrogen (NPN), whose main source used is urea, nutritionally important to adjust the ration on rumen degradable protein (RDP) and economically important to lower the cost of protein supplementation; non-protein nitrogen of slow release in the rumen (protected urea); and protein nitrogen, whose source used can be rich, intermediate or low in RDP. Therefore, the RDP 
usage efficiency in rumen is a central factor in determining the economic cost and impact on the ruminant production system.

Therefore, more information is needed for adoption of protein supplementation during the rainy period and dry-water transition period, since the studies are limited in relation to the individual contributions of RDP, rumen undegradable protein (RUP), or metabolizable protein (MP) on animal performance and, especially, the economic viability of different protein supplements compared to standard mineral supplementation.

Because of the lack of this information, this work was carried out to evaluate the effect of different protein supplements on the performance and economic viability of Nellore calves under grazing of Brachiaria brizantha cv. Xaraés during the rainy and dry-water transition periods.

\section{Materials and Methods}

The experiment was carried out on the Farm Retiro, located in the municipality of Barra do Bugres (Mato Grosso, MT, Brazil), from February to May 2011, the period featured with season of waters and dry-water transition periods. 80 Nellore non-castrated calves were used, averaging 25 months of age and body weight $371 \pm 11.3 \mathrm{~kg}$.

The total experimental period was 84 days, divided into four periods of 28 days each. Initially, the animals were weighed, identified with ear earrings and treated against ectoparasites and endoparasites by administering (broad-spectrum antiparasitic drug in the avermectin family) ivermectin (Ivomec; Merial, Paulínia, Brazil), and allocated in the experimental area consisting of four 12-hectare paddocks each, established with Brachiaria brizantha cv. Xaraés. All paddocks had natural water fountains and covered salt troughs: $3 \mathrm{~m}$ long, $40 \mathrm{~cm}$ top base, $30 \mathrm{~cm}$ bottom base and $30 \mathrm{~cm}$ depth. The animals were distributed in a completely randomized design (20 animals per treatment).
The supplements were fed ad libitum and replaced every two or three days, according to the demand consumed by the animals. The supplements were: MS - Mineral supplement (control) containing $80 \mathrm{~g}$ of phosphorus / $\mathrm{kg}$ of supplement; PMS 20\% FS - Protein and mineral supplement with 20\% crude protein (CP), consisting in maize, soybean meal, urea and mineral mixture; PMS $40 \%$ UR - Protein and mineral supplement with 40\% CP consisting in maize, urea and mineral mixture; PMS 40\% UP - Protein and mineral supplement with $40 \%$ CP consisting in maize, urea, mineral mixture and protected urea (substituting $67.85 \%$ of urea of treatment PMS 40\% UR).

MS 20\% FS was formulated with assurance levels $50 \%$ lower than the assurance levels of MS $40 \%$ UR and MS 40\% UP, with the exception of sodium macro-element $(\mathrm{Na})$ with $43.45 \%$ of the $\mathrm{Na}$ present in the MS 40\% UR and MS 40\% UP (Table 1). This difference was due to the adjustment for better intake. The animals were weighed at the beginning and end of the experiment, February 18, 2011 and May 13, 2011, after undergoing fasting of solid food and liquids for 16 hours.

To minimize the influence of possible variation in the forage mass (FM) and quality of forage available between experimental paddocks, animal rotations were performed every 21 days between experimental paddocks, keeping the supply of the same supplements to animals in each treatment, so that at the end of the experiment all animals had access to the four pastures. Rainfall data were collected during the trial period, with 208, 235, 170 and $50 \mathrm{~mm}$ for the months of February, March, April and May, respectively, in order to better observe rainfall influence on the environment of pastures.

To estimate total forage availability in the paddocks, three samples were taken: in the beginning $(02 / 18 / 2011)$, in the middle $(04 / 01 / 2011)$ and in the end $(05 / 13 / 2011)$ of the trial period, through cutting forage at $5 \mathrm{~cm}$ above the ground on 15 points, randomly within each experimental paddock, 
using a $0.5 \times 0.5 \mathrm{~m}$ metal square (McMENIMAN, 1997). After collection, each sample was weighed and homogenized and, from these, two composite samples were taken. A sample was used to assess the overall availability of DM and another one for analysis of DM and iNDF.

Table 1. Percentage composition of the supplements and assurance levels based on natural raw.

\begin{tabular}{lcccc}
\hline & \multicolumn{4}{c}{ Treatments $^{\mathbf{1}}$} \\
\cline { 2 - 5 } Item & MS & PMS 20\% FS & PMS 40\% UR & PMS 40\% UP \\
\hline Soybean meal (\%) & - & 11.70 & - & - \\
Maize (\%) & - & 17.50 & 35.00 & 35.00 \\
Urea (\%) & - & 5.00 & 13.19 & 5.00 \\
Protected urea (\%) & - & & & 8.95 \\
Salt (\%) & 35 & 7.30 & 16.80 & 16.80 \\
Mineral mixture (\%) & 65 & 17.00 & 34.00 & 34.00 \\
Vehicle QSP - Kaolinite (\%) & - & 41.50 & 1.01 & 0.25 \\
$\mathrm{CP}(\%)$ & 0 & 20 & 40 & 40 \\
$\mathrm{Ca}(\mathrm{g} / \mathrm{kg})$ & 150.00 & 50.00 & 100.00 & 100.00 \\
$\mathrm{P}(\mathrm{g} / \mathrm{kg})$ & 80.00 & 15.00 & 30.00 & 30.00 \\
$\mathrm{Mg}(\mathrm{g} / \mathrm{kg})$ & 10.00 & 2.50 & 5.00 & 5.00 \\
$\mathrm{~S}(\mathrm{~g} / \mathrm{kg})$ & 15.00 & 5.00 & 10.00 & 10.00 \\
$\mathrm{Na}(\mathrm{g} / \mathrm{kg})$ & 130.00 & 28.00 & 64.00 & 64.00 \\
$\mathrm{Co}(\mathrm{mg} / \mathrm{kg})$ & 200.00 & 30.00 & 60.00 & 60.00 \\
$\mathrm{I}(\mathrm{mg} / \mathrm{kg})$ & 130.00 & 20.00 & 40.00 & 40.00 \\
$\mathrm{Mn}(\mathrm{mg} / \mathrm{kg})$ & $1,400.00$ & 160.00 & 320.00 & 320.00 \\
$\mathrm{Se}(\mathrm{mg} / \mathrm{kg})$ & 20.00 & 3.00 & 6.00 & 6.00 \\
$\mathrm{Zn}(\mathrm{mg} / \mathrm{kg})$ & $5,000.00$ & $1,000.00$ & $2,000.00$ & $2,000.00$ \\
$\mathrm{Cu}(\mathrm{mg} / \mathrm{kg})$ & $1,500.00$ & 300.00 & 600.00 & 600.00 \\
\hline $\mathrm{SM}-\mathrm{min}$
\end{tabular}

${ }^{1} \mathrm{SM}$ - mineral supplement; PMS 20\% FS - mineral-protein with $20 \%$ of CP consisting in true protein; PMS $40 \%$ UR - mineralprotein with $40 \%$ of CP consisting of urea; PMS 40\% UP - mineral-protein with $40 \%$ of CP consisting in protected urea.

From the samples for the estimation of total dry matter (TDM), the percentage of potentially digestible dry matter (pdDM) offered to the animals was calculated, whose value was obtained by means of the insoluble residue in neutral detergent solution, assessed after the samples in situ incubation for 240 hours, in accordance with Casali et al. (2008), by means of the equation proposed by Paulino et al. (2006).

In these same periods, the sampling of the pasture consumed by the animals was carried out via manual grazing simulation at 15 different points, chosen at random, to the fullest extent of each paddock. This harvest was carried out exclusively by a single person in order to avoid variations inherent in the form of collection of each researcher.

The collected forage samples were sent to have their chemical composition determined at Laboratório de Nutrição Animal (Animal Nutrition Laboratory) at Universidade Federal do Mato Grosso, UFMT, where they were pre-dried in a forced ventilation oven at a temperature of $60 \pm$ $5{ }^{\circ} \mathrm{C}$ for 72 hours and, subsequently, ground in a Wiley knives mill equipped with a $1.0 \mathrm{~mm}$ mesh sieve and stored in plastic vials with lid, properly identified. 
The forage samples obtained by grazing simulation were analyzed to determine the levels of dry matter (DM), mineral matter (MM), crude protein $(\mathrm{CP})$ and ether extract $(\mathrm{EE})$, according to the Association of Official Analytical Chemists (AOAC, 1995). The insoluble residue in neutral detergent solution (NDF) and insoluble residue in acid detergent solution (ADF) were determined following the methodologies from Van Soest et al. (1991). As for the Neutral Detergent Insoluble Nitrogen (NDIN) and acid detergent insoluble nitrogen (ADIN), they were performed according to techniques proposed by Licitra et al. (1996). The total carbohydrate content of grasses (TC) was obtained by the equation proposed by Sniffen et al. (1992).

Regarding the animals' performance, the average daily gain (ADG) and the total weight gain (TWG) were assessed, depending on the various proposed treatments. As for the economic evaluation, spreadsheets were used to estimate the production costs and economic indicators: gross margin, net margin, profit and return on invested capital (ROIC). The evaluation of the economic viability was based on the methodology proposed by Frank (1978). For this, the following indicators were used: gross margin (total revenue - variable operating costs); operating income or net margin (total revenue - total operating cost); and total profit (total revenue - total cost).

Ultrasonography measurements in real time were carried out on all animals using the collected images to determine the subcutaneous fat thickness (SFT), measured between the area of the $12^{\text {th }}$ and $13^{\text {th }}$ ribs, transversely to the muscleLongissimus dorsi. Additionally, images were collected to measure the subcutaneous fat thickness on the rump (SFT8) measured at the intersection of muscles Gluteus medius and Biceps femoris, located between the ileum and ischium. The different supplementation strategies were evaluated according to the accumulation rate of fat thickness in Longissimus dorsi (SFTRate) and the accumulation rate on the rump (SFT8Rate), calculated by dividing the difference of the final and initial measurements by the number of trial days. The device that was used to make images was of the brand ALOKA $500 \mathrm{~V}$, with a linear probe of $17.2 \mathrm{~cm}$, of $3.5 \mathrm{MHz}$. The images were interpreted using the software "Biosoft Toolbox" (Biotronics Inc., Ames, IA, EUA). To collect the images, vegetable oil and a coupling ("standoff") were used to ensure the acoustic contact between the linear probe and the animal's body.

The data were analyzed in a completely randomized design (CRD) with 20 repetitions per treatment, subjected to analysis of variance using the statistical package SAS (Statistical Analysis System, version 9.0). When significant, the treatment means were compared using the Tukey test. In all analyzes, significance was declared in $\mathrm{P} \leq 0.05$.

\section{Results and Discussion}

The average availability of total dry matter (TDM) and potentially digestible dry matter (pdDM) of pasture of Brachiaria brizantha cv. Xaraés during the experimental period were of 5,124 and 4,153 kg/ha, respectively (Table 2). According to Paulino et al. (2002), pdDM availability should be 4 to $5 \%$ of body weight (BW), so that there is a satisfactory performance of cattle raised in pasture. In this experiment, the availability of TDM and pdDM for cattle, expressed as a percentage of the BW, was $7.44 \%$ and $6.03 \%$, respectively, providing conditions for the animals to perform selective grazing, without hindering performance due to the amount of available forage. Moreover, the forage presented a crude protein value of $10.70 \%$. However, part of the total nitrogen content is presented in the form of neutral detergent insoluble nitrogen (NDIN) and acid detergent insoluble nitrogen (ADIN), with levels of $28.91 \%$ and 10.66 $\%$, respectively (Table 2 ). 
Table 2. Chemical composition, availability of total dry matter (total DM) and potentially digestible dry matter (pdDM) of Brachiaria brizantha cv. Xaraés in the experimental periods.

\begin{tabular}{lcccc}
\hline & \multicolumn{3}{c}{ Experimental months } & Mean \\
\cline { 2 - 4 } \multicolumn{1}{c}{ Item } & February & April & May & 36.11 \\
$\mathrm{DM}, \%$ & 34.27 & 35.78 & 38.30 & 10.70 \\
$\mathrm{CP}^{1}$ & 11.62 & 12.25 & 8.24 & 5.74 \\
$\mathrm{MM}^{1}$ & 6.41 & 5.26 & 5.54 & 2.37 \\
$\mathrm{EE}^{1}$ & 2.71 & 2.37 & 2.03 & 61.69 \\
$\mathrm{NDF}^{1}$ & 58.35 & 62.11 & 64.61 & 18.16 \\
$\mathrm{iNDF}^{1}$ & 15.96 & 18.53 & 20.00 & 30.29 \\
$\mathrm{ADF}^{1}$ & 27.62 & 32.22 & 31.04 & 81.19 \\
$\mathrm{TC}^{1}$ & 79.25 & 80.12 & 84.19 & 28.91 \\
$\mathrm{NDIN}^{2}$ & 30.12 & 25.51 & 31.10 & 10.66 \\
$\mathrm{ADIN}$ & & 9.18 & 13.65 & 5,124 \\
Total DM, kg/ha & 9.14 & 5,579 & 5,661 & 4,153 \\
pdDM, kg/ha & 4,132 & 4,516 & 4,500 & \\
\hline
\end{tabular}

${ }^{1}$ of the dry matter; ${ }^{2} \%$ of the total N; DM - dry matter; CP - crude protein; MM - mineral matter; EE - ether extract; NDF - neutral detergent fiber; iNDF - indigestible neutral detergent fiber; ADF - acid detergent fiber; TC - total carbohydrates; NDIN - Neutral Detergent Insoluble Nitrogen; and ADIN - acid detergent insoluble nitrogen.

All supplements of this experiment were formulated aimed at self-regulation of the intake by animals. Thereby, the PMS $40 \%$ UP treatment presented an additional intake of $12.4 \mathrm{~g}$ /day of $\mathrm{CP}$ and $18.19 \mathrm{~g} /$ day of RDP regarding the PMS $20 \% \mathrm{FS}$ treatment. As for the PMS $40 \%$ UR treatment, PMS $40 \%$ UP had a higher intake in $5.2 \mathrm{~g} /$ day $\mathrm{CP}$ and $4.95 \mathrm{~g} /$ day of RDP (Table 3 ).

Table 3. Average daily intake of supplements, average daily intake of crude protein (CP), rumen degradable protein (RDP) and total digestible nutrients (TDN).

\begin{tabular}{lcccc}
\hline & \multicolumn{3}{c}{ Treatments $^{1}$} \\
\cline { 2 - 5 } Item & MS & PMS 20\% FS & PMS 40\% UR & PMS 40\% UP \\
\hline Supplement, g/day & 91 & 410.00 & 223.00 & 236.00 \\
PB $^{2}$, g/day & - & 82.00 & 89.20 & 94.40 \\
$\mathrm{RDP}^{2}$, g/day & - & 71.66 & 84.95 & 89.85 \\
$\mathrm{TDN}^{2}$, g/day & - & 89.01 & 61.82 & 65.42 \\
\hline
\end{tabular}

${ }^{1} \mathrm{SM}$ - mineral supplement; PMS 20\% FS - mineral-protein with $20 \%$ of CP consisting in true protein; PMS $40 \%$ UR - mineralprotein with $40 \%$ of CP consisting of urea; PMS $40 \%$ UP - mineral-protein with $40 \%$ of CP consisting in protected urea.

${ }^{2}$ Estimated intake according to the average daily intake of the supplements and with the chemical composition of the ingredients used.

The animals that received the PMS 40\% UP supplement obtained higher TWG and ADG $(\mathrm{P}<$ $0.05)$ than what was observed in the animals that received the control treatment (MS), being greater by $110 \mathrm{~g} /$ day, representing $11.6 \%$ of additional gain compared to the MS treatment (Table 4). There was no difference $(\mathrm{P}>0.05)$ in $\mathrm{ADG}$ and TWG in the PMS 40\% UR and PMS 20\% FS treatments 
regarding the MS treatment. Also, no difference was observed $(\mathrm{P}>0.05)$ in ADG and TWG among treatments PMS 40\% UP, PMS 40\% UR and PMS $20 \%$ FS. However, a numerical increment for ADG of the animals that received the PMS 40\% UP treatment in relation to the ones that received PMS $40 \%$ UR and PMS $20 \%$ FS of $50 \mathrm{~g} /$ day or $4.95 \%$ and $90 \mathrm{~g} /$ day or $9.28 \%$, respectively, was observed.

Table 4. Mean, standard error of the mean (SEM) and significance level of initial body weight (IBW), final body weight (FBW), total weight gain (TWG) and average daily gain (ADG) among the experimental treatments.

\begin{tabular}{|c|c|c|c|c|c|c|}
\hline \multirow[b]{2}{*}{ Item } & \multicolumn{4}{|c|}{ Treatments $^{1}$} & \multirow[b]{2}{*}{ EPM } & \multirow[b]{2}{*}{ p-value } \\
\hline & MS & PMS 20\% FS & PMS 40\% UR & PMS 40\% UP & & \\
\hline IBW, kg & 372.11 & 371.15 & 371.00 & 371.00 & 1.28 & 0.91 \\
\hline FBW, kg & 451.95 & 452.70 & 455.85 & 459.75 & 1.65 & 0.33 \\
\hline TWG, kg & $79.84^{\mathrm{b}}$ & $81.55^{\mathrm{ab}}$ & $84.85^{\mathrm{ab}}$ & $88.75^{\mathrm{a}}$ & 1.16 & 0.03 \\
\hline ADG, $\mathrm{kg}$ /day & $0.95^{\mathrm{b}}$ & $0.97^{\mathrm{ab}}$ & $1.01^{\mathrm{ab}}$ & $1.06^{\mathrm{a}}$ & 0.14 & 0.03 \\
\hline
\end{tabular}

${ }^{a-b}$ Different letters in the same row indicate that there were differences by Tukey test at $5 \%$ significance.

${ }^{1} \mathrm{SM}$ - mineral supplement; PMS $20 \%$ FS - mineral-protein with $20 \%$ of CP consisting in true protein; PMS $40 \%$ UR - mineralprotein with $40 \%$ of CP consisting of urea; PMS $40 \%$ UP - mineral-protein with $40 \%$ of CP consisting in protected urea.

Even working with different supplements and protein sources, our results were similar to the experiments by Figueiredo et al. (2008) and Zervoudakis et al. (2002), where animals that consumed higher amounts of rumen degradable protein (RDP) via supplement had a superiority in ADG during the trial period. According to Detmann et al. (2010), during the rainy period the mass of organic matter degraded in the rumen can be greater in about $80 \%$ relative to the dry period, which would expand in demand for urea (RDP) for maintaining microbial growth in the rumen.

As for the animal carcass characteristics, when analyzing the rump area there was no effect $(\mathrm{P}>$ $0.10)$ of the treatments on the initial fat thickness (SFT8i), final fat thickness (SFT8f), and fat accumulation rate (SFT8Rate). Relative to the position of the muscle Longuissimus dorsi, there was no effect $(\mathrm{P}=0.132)$ of treatments on the final fat thickness (fSFT). However, the animals supplemented with treatment PMS 40\% UP showed a fat accumulation rate in muscle Longuissimus dorsi (SFTRate) that was higher $(\mathrm{P}=0.093)$ than in the animals supplemented with SPM $40 \%$ UR (Table 5). Whereas fibrolytic microorganisms use rumen ammonia nitrogen (RAN) as the main nitrogen precursor for growth (RUSSELL, 2002), this superiority in SFTRate is possibly related to increased growth of these microorganisms caused by higher intake of CP and RDP via PMS UP $40 \%$ in relation to the PMS $40 \%$ UR treatment, promoting an increase in the digestion of food consumed and therefore higher amount of energy. 
Table 5. Average, standard error of the mean (SEM) and the significance level for the initial fat thickness (SFT8i), final fat thickness (SFT8f) and fat accumulation rate in the rump region (SFT8Rate), and thickness of initial fat (iEGLD) end (fEGLD) and muscle fat accumulation rate Longissimus dorsi (SFTRate).

\begin{tabular}{lcccccc}
\hline & \multicolumn{5}{c}{ Treatments $^{\mathbf{1}}$} & \\
\cline { 2 - 5 } Item & MS & PMS 20\% FS & PMS 40\% UR & PMS 40\% UP & EPM & p-value \\
\hline SFT8i, mm & 2.875 & 2.875 & 2.925 & 2.677 & 0.060 & 0.892 \\
SFT8f, mm & 3.950 & 4.225 & 4.072 & 4.095 & 0.013 & 0.912 \\
SFT8Rate, mm/day & 0.012 & 0.015 & 0.013 & 0.016 & 0.001 & 0.657 \\
iSFT, mm & 2.575 & 2.650 & 2.722 & 2.677 & 0.046 & 0.873 \\
FSFT, mm & 3.875 & 4.050 & 3.757 & 4.320 & 0.092 & 0.132 \\
SFTRate, mm/day & $0.014^{\mathrm{ab}}$ & $0.016^{\mathrm{ab}}$ & $0.011^{\mathrm{b}}$ & $0.018^{\mathrm{a}}$ & 0.001 & 0.093 \\
\hline
\end{tabular}

a-b Different letters in the same row indicate that there were differences by Tukey test at $10 \%$ significance.

${ }^{1} \mathrm{SM}$ - mineral supplement; PMS 20\% FS - mineral-protein with 20\% of CP consisting in true protein; PMS $40 \%$ UR - mineralprotein with $40 \%$ of CP consisting of urea; PMS $40 \%$ UP - mineral-protein with $40 \%$ of CP consisting in protected urea.

This result can also be explained by the slow rate of protected urea release in the rumen over traditional urea. With the slowest rate of release, the utilization of nitrogen in the rumen by microorganisms is increased and may increase the digestibility of food. Oliveira et al. (2006) found that urea showed a disappearance rate of $100 \%$ in 30 minutes and that the degradation of the protected urea occurred in a maximum time of 12 hours, having a release peak in 3 hours.
Total fixed cost was the same in all treatments (Table 6), aimed at economic equity at the beginning of the experiment, considering the body weight at entry into the experiment as 12.4 arroba (modern metric arroba is defined as 15 kilograms (33 lb)) and animal purchase price of $\mathrm{R} \$ 90.00$ / arroba, totaling $\mathrm{R} \$ 1,116.00$ / animal, added to the cost of R $\$ 33.60$ for the grazing lease in the period of 84 days, totaling R\$ $1,149.60$ / animal. The grazing lease cost was regarded as fixed costs due to the establishment of its values prior to the start of the experiment.

Table 6. Economic indicators of production per animal in the different treatments due to the average performance in the trial period.

\begin{tabular}{|c|c|c|c|c|}
\hline \multirow[t]{2}{*}{ Item } & \multicolumn{4}{|c|}{ Treatments } \\
\hline & MS & PMS 20\% FS & PMS 40\% UR & PMS 40\% UP \\
\hline \multicolumn{5}{|l|}{ Fixed cost } \\
\hline Animal - beginning of the experiment $(\mathrm{R} \$)^{2}$ & $1,116.00$ & $1,116.00$ & $1,116.00$ & $1,116.00$ \\
\hline Pasture-animal period 84 days $(\mathrm{R} \$)^{2}$ & 33.60 & 33.60 & 33.60 & 33.60 \\
\hline Total fixed costs per animal $(\mathrm{R} \$)$ & $1,149.60$ & $1,149.60$ & $1,149.60$ & $1,149.60$ \\
\hline \multicolumn{5}{|l|}{ Variable operating costs } \\
\hline Labor/84 days $(\mathrm{R} \$)^{2}$ & 127.68 & 127.68 & 127.68 & 127.68 \\
\hline Supplement (R $\$ / k g)$ & 1.20 & 0.77 & 1.02 & 1.24 \\
\hline Supplement intake (g/day) & 91.00 & 410.00 & 223.00 & 236.00 \\
\hline Supplement total intake (kg/84 days) & 7.64 & 34.44 & 18.73 & 19.82 \\
\hline Cost of supplementation / Animal day (R\$) & 0.11 & 0.32 & 0.23 & 0.29 \\
\hline
\end{tabular}


... Continuation

\begin{tabular}{lcccc}
\hline Total cost of supplementation (R / Animal / 84 days) & 9.24 & 26.88 & 19.32 & 24.36 \\
Cost differential of PMS x MS (\%) & --- & 190.91 & 109.09 & 163.64 \\
Total variable cost per animal (R\$) & 136.92 & 154.56 & 147.00 & 152.04 \\
Cost per arroba produced $(\mathrm{R} \$)^{4}$ & 49.47 & 54.67 & 49.98 & 49.42 \\
\hline Total cost of the experiment per animal (R\$) & $1,286.52$ & $1,304.16$ & $1,296.60$ & $1,301.64$ \\
Opportunity cost $\left(1 \%\right.$ per month) $(\mathrm{R} \$)^{5}$ & 36.02 & 36.52 & 36.30 & 36.45 \\
Total cost of the experiment + opportunity cost (R\$) & $1,322.54$ & $1,340.68$ & $1,332.90$ & $1,338.09$ \\
Total revenue (R\$) & $1,437.17$ & $1,439.59$ & $1,449.60$ & $1,462.01$ \\
Gross margin $(\mathrm{R} \$)^{5}$ & $1,300.25$ & $1,285.03$ & $1,302.60$ & $1,309.97$ \\
Net margin $(\mathrm{R} \$)^{7}$ & 114.63 & 98.91 & 116.70 & 123.92 \\
Differential ML $(\mathrm{R} \$)^{8}$ & ---- & -15.72 & 2.07 & 9.29 \\
Differential ML 84 days $(\%)^{9}$ & ---- & -13.71 & 1.81 & 8.10 \\
Return on invested capital $(\%)^{10}$ & 8.91 & 7.58 & 9.00 & 9.52 \\
\hline
\end{tabular}

${ }^{1}$ Additional ADG regarding the control. ${ }^{2}$ Cost of pasture $=\mathrm{R} \$ 12.00 / \mathrm{month} / 30$ days $\mathrm{x} 84$ days $=\mathrm{R} \$ 33.60$ and 12.4 arroba of oxen at the beginning of the experiment. ${ }^{*} \mathrm{R} \$ 90$ arroba $=\mathrm{R} \$ 1,116.00 .{ }^{3}$ Monthly salary with charges $=\mathrm{R} \$ 2,280.00 / 30$ days $=\mathrm{R} \$$ 76.00 per day $/ 1,000$ oxen $=\mathrm{R} \$ 0.076$ per ox $* 84$ days (period of the experiment). $* 20$ oxen for treatment $=\mathrm{R} \$ 127.68 .{ }^{4} \mathrm{Cos}$ per arroba produced $=$ total variable cost per animal / total gain. $* 52 \%$ beef carcass yield. ${ }^{5}$ Total cost of the experiment per animal. $* 1 \%$ per month $=2.8 \%$ in 84 days. ${ }^{6}$ Total revenue (total cost of the experiment + opportunity cost). ${ }^{7}$ Total revenue - Gross margin. ${ }^{8} \mathrm{R} \$$ Treatments versus Control. ${ }^{9 \%} \%$ Treatments versus Control. ${ }^{10} \mathrm{Net}$ margin / Total cost of the experiment per animal. Price values for beef cattle arroba, inputs and labor were rated according to indicators by IMEA (2011).

The supplementation cost per animal in the period of 84 days was R\$ 9.24; 26.88; 19.32; and 24.36 respectively in treatments MS, PMS 20\% FS, PMS 40\% UR, and PMS 40\% UP. The supplementation showed higher cost in $190.01 \% ; 109.09 \%$; and $163.64 \%$, respectively, in treatments PMS 20\% FS, PMS 40\% UR, and PMS 40\% UP regarding MS treatment. Even with higher supplementation cost in $163.64 \%$ of the PMS $40 \%$ UP treatment compared to MS treatment, it was noted that the cost per produced arroba in the period was about the same for these two treatments, being R\$ 49.47/ arroba for MS and R\$ 49.42/arroba for PMS 40\% UP. This amount was possible only due to spreading the total cost by the greater weight gain during the trial period in the PMS 40\% UP treatment.

The net margin was positive in all treatments. Therefore, treatment PMS 20\% FS presented a differential of negative net margin in relation to the MS treatment, amounting to - R $\$ 15.72$ or $-13.71 \%$ per animal over a period of 84 days. The higher cost of supplementation and the lowest additional gain compared to the control treatment (MS) were the factors responsible for making uneconomic the use of the supplement PMS 20\% FS. The net margin differentials per animal in the experimental period compared to the MS treatment were of R $\$ 2.07$ or $1.81 \%$ in the PMS 40\% UR treatment and R $\$ 9.29$ or $8.1 \%$ in the PMS $40 \%$ UP treatment.

Results demonstrating economic viability similar to this study were found by Barbosa et al. (2008) when assessing the economic viability of protein supplementation, considering different levels and daily intake of supplements: $0.17 \%$ (SUP1) and $0.37 \%$ (SUP2) of body weight compared to control treatment (MS), obtaining higher gross profit in the animals receiving protein supplementation compared to control treatment (MS). The results were of R $\$ 59.92$ in treatment (SUP2), R\$ 55.10 in treatment (SUP1) and R\$ 54.85 in treatment (MS) per animal during the experimental period. The differential of the total profit varied at $0.45 \%$ in treatment (SUP1) and $9.24 \%$ in treatment (SUP2) compared to the control treatment (MS). 
Malafaia et al. (2003) have stressed that the use of multiple supplements at low levels of supply can also bring a positive economic return. Cabral et al. (2011) have found that the animals' performance showed no statistical difference $(\mathrm{P}>$ $0.05)$ when they consumed protein supplements with $20 \%$ and $40 \%$ of crude protein compared to the control treatment with mineral supplement, in the rainy season, finding greater economic viability for mineral supplementation compared with protein supplements with $20 \%$ and $40 \%$ of crude protein. This result was due to the poor performance obtained from animals fed protein supplements, being unable to spread the total variable costs for profits higher than the control treatment. This result is consistent with the findings in this study, in treatment PMS $20 \%$ FS, with net margin differential of $-13.57 \%$ compared to the control treatment (MS).

The data from this experiment showed that the nitrogen source used in the formulation of the protein and mineral supplement for beef cattle grazing during the rainy and dry-water transition periods can have negative or positive economic results compared with the mineral supplementation, ranging from $-13.57 \%$ to $8.1 \%$. These results are based only on the supplementation direct gain, where the main variables are ADG and the supplementation cost in the period.

Regarding the implications of this study for beef cattle in Brazil, it was observed that protein supplement for cattle may benefit not only directly but also indirectly the production system, promoting anticipation of animal slaughter age and higher product gains by area ( $\mathrm{kg}$ of meat $/ \mathrm{ha}$ ), reducing the farm time and thereby increasing the full profitability of the production system. Another key point of protein supplementation for animals is to supply the nitrogen deficiency that tropical grasses have, thus being able to meet the nutritional requirements of animals for high levels of desired performance. Moreover, this strategy of increasing the efficiency gains during the growing phase can influence the profitability of the integrated system of cattle raised on pasture and ending in feedlot in Brazil.

\section{Conclusions}

Supplement PMS 40\% UP provides additional average daily gain of $110 \mathrm{~g}$ /animal or $11.6 \%$ compared to mineral supplementation (MS), promotes superiority in fat accumulation rate in muscle Longissimus dorsi in relation to supplement PMS 40\% UR. Besides, supplements PMS 40\% UR and PMS 40\% UP have economic viability in relation to $\mathrm{MS}$, with higher net margin differential at $1.81 \%$ and $8.10 \%$, respectively.

\section{References}

ASSOCIATION OF OFFICIAL ANALYTICAL CHEMISTS - AOAC. International official methods of analysis. $16^{\text {th }}$ ed. Gaithersburg: AOAC International, $19951025 \mathrm{p}$.

BANDYK, C. A.; CONCHRAN, T. A.; WICKERSHAM, E. C.; TITGEMEYER, E. C.; FARMER, C. G.; HIGGINS, J. J. Effect of ruminal vs. postruminal administration of degradable protein on utilization of low-quality forage by beef steers. Journal of Animal Science, Champaign, v. 79, n. 1, p. 225-231, 2001.

BARBOSA, F. A.; GRAÇA, D. S.; GUIMARÃES, P. H. S.; SILVA JÚNIOR, F. V. Análise econômica da suplementação proteico-energética de novilhos durante o período de transição entre águas e seca. Arquivo Brasileiro de Medicina Veterinária e Zootecnia, Belo Horizonte, v. 60, n. 4, p. 911-916, 2008.

CABRAL, C. H. A.; BAUER, M. O.; CARVALHO, R. C.; CHICHORRO, F. F.; SOUZA, A. L.; SOUZA, C. S. Suplementação proteica de bovinos na época das águas em pastagem de Brachiaria brizantha. II. Viabilidade econômica. Revista Caatinga, Mossoró, v. 25, n. 3, p. 173-181, 2011.

CASALI, A. O.; DETMANN, E.; VALADARES FILHO, S. C.; PEREIRA, J. C.; HENRIQUES, L. T.; FREITAS, S. G.; PAULINO, M. F. Influência do tempo de incubação e do tamanho de partículas sobre os teores de compostos indigestíveis em alimentos e fezes bovinas obtidos por procedimento in situ. Revista Brasileira de Zootecnia, Viçosa, MG, v. 37, n. 2, p. 335-342, 2008. 
COSTA, V. A. C.; DETMANN, E.; PAULINO, M. F.; VALADARES FILHO, S. C.; CARVALHO, I. P. C.; MONTEIRO, L. P. Digestibilidade parcial e total e balanço nitrogenado em bovinos em pastejo no período das águas recebendo suplementos com nitrogênio não proteico e/ou proteína verdadeira. Revista Brasileira de Zootecnia, Viçosa, MG, v. 40, n. 12, p. 2815-2826, 2011.

DETMANN, E.; PAULINO, M. F.; VALADARES FILHO, S. C. Otimização do uso de recursos forrageiros basais. In: SIMPÓSIO DE PRODUÇÃO DE GADO DECORTE, 7., 2010, Viçosa, MG. Anais... Viçosa, MG: DZO-UFV, 2010. p. 191-240.

FIGUEIREDO, D. M.; PAULINO, M. F.; DETMANN, E.; SOUZA, M. G.; COUTO, V. R. M.; SALES, M. F. L. Estratégia de suplementação para antecipação da idade à puberdade para novilhas de corte em pastagem tropical. Acta Scientiarum, Maringá, v. 30, n. 4, p. 415-423, 2008.

FRANK, R. G. Introducción al cálculo de costos agropecuários. Buenos Aires: El Ateneo, 1978. 34 p.

INSTITUTO MATO-GROSSENSE DE ECONOMIA AGRÍCOLA - IMEA. Boi a vista. Cuiabá: FAMATO, 2011. Disponível em: <http://www.imea.com.br/precos. php>. Acesso em: 10 maio 2011.

KNORR, M.; PATINO, H. O.; SILVEIRA, A. L. F.; MÜHLBACH, P. R. F.; MALLMANN, G. M.; MEDEIROS, F. S. Desempenho de novilhos suplementados com sais proteinados em pastagem nativa. Pesquisa Agropecuária Brasileira, Brasília, v. 40, n. 8, p. 783-788, 2005.

KÖSTER, H. H.; COCHRAN, R. C.; TITGEMEYER, E. C.; VANZANT, E. S.; ABDELGADIR, I.; ST-JEAN, G. Effect of increasing degradable intake protein on intake and digestion of low-quality tallgrass-prairie forage by beef cows. Journal of Animal Science, Champaign, v. 74, n. 10, p. 2473-2481, 1996.

LICITRA, G.; HERNANDEZ, T. M.; VAN SOEST, P. J. Standardization of procedures for nitrogen fractionation of ruminant feeds. Animal Feed Science Technology, Amsterdam, v. 57, n. 4, p. 347-358, 1996.

MALAFAIA, P.; CABRAL, L. S.; VIEIRA, R. A. M.; COSTA, R. M.; CARVALHO, C. A. B. Suplementação proteico - energética para bovinos criados em pastagens: aspectos teóricos e principais resultados publicados no Brasil. Livestock Research for Rural Development, Cali, v. 15, n. 12, 2003.

McMENIMAN, N. P. Methods of estimating intake of grazing animals. In: SIMPÓSIO SOBRE TÓPICOS ESPECIAIS EM ZOOTECNIA, 1997, Juiz de Fora. Anais... Juiz de Fora: SBZ, 1997. p. 133-168.
OLIVEIRA, L. G.; FERREIRA, R. N.; MAGALHÃES, P. H. Curva de liberação de N-NH3 de ureia e ureia encapsulada com polímero (OPTIGEN 1200®) em ruminantes. In: CONGRESSO DE ENSINO PESQUISA E EXTENSÃO DA UFG - CONPEX, SEMINÁRIO DE INICIAÇÃO CIENTÍFICA, 3, 14., 2006, Goiânia. Anais... Goiânia: UFG, 2006. CD-ROM.

PAULINO, M. F. Suplementos múltiplos para recria e engorda de bovinos em pastagens. In: CONGRESSO NACIONAL DOS ESTUDANTES DE ZOOTECNIA, 1998, Viçosa, MG. Anais... Viçosa, MG: AMEZ, 1998. p. 173-188.

PAULINO, M. F.; MORAES, E. H. K. B.; ZERVOUDAKIS, J. T. Suplementação de novilhos mestiços recriados em pastagens de Brachiaria decumbens durante o período das águas: desempenho. In: REUNIÃO ANUAL DA SOCIEDADE BRASILEIRA DE ZOOTECNIA, 39., 2002, Recife. Anais... Recife: Sociedade Brasileira de Zootecnia, 2002. CD-ROM.

PAULINO, M. F.; ZAMPERLINI, B.; FIGUEIREDO, D. M.; MORAES, E. H. B. K.; FERNANDES, H. J.; PORTO, M. O.; SALES, M. F. L.; PAIXÃO, M. L.; ACEDO, T. S.; DETMANN, E.; VALADARES FILHO, S. C. Bovinocultura de precisão em pastagens In: SIMPÓSIO DE PRODUÇÃO DE GADO DE CORTE, 5., 2006, Viçosa, MG. Anais... Viçosa, MG: SIMCORTE, 2006. p. 392-394.

RUSSELL, J. B. Rumen microbiology and its role in ruminant nutrition. Ithaca: James B. Russell, 2002. 119 p.

SANTOS, F. A. P. Metabolismo de proteínas. In: BERCHIELLI, T. T.; VAZ PIRES, A.; OLIVEIRA, S. G. de. Nutrição de ruminantes. Jaboticabal: Funep, 2006. cap. 10 , p. $255-284$.

SNIFFEN, C. I.; O'CONNOR, I. D.; VAN SOEST, P. I.; FOX, D. G.; RUSSEL, J. B. A net carbohydrate and protein system for evaluating cattle diets: II. Carbohydrate and protein availability. Journal of Animal Science, Champaign, v. 70, n. 12, p. 3562-3577, 1992.

VAN SOEST, P. J. Nutritional ecology of the ruminant. $2^{\text {th }}$ ed. New York: Cornell University Press, 1994. 476 p.

VAN SOEST, P. J.; ROBERTSON, J. B.; LEWIS, B. A. Methods for dietary fiber, Neutral detergent fiber, and non starch polysaccharides in relation to animal nutrition. Journal of Dairy Science, Champaign, v. 74, n. 10, p. 3583-3597, 1991. 
ZERVOUDAKIS, J. T.; PAULINO, M. F.; DETMANN, E.; VALADARES FILHO, S. C.; LANA, R. P.; CECON, P. R. Desempenho de novilhas mestiças e parâmetros ruminais em novilhos suplementados durante o período das águas. Revista Brasileira de Zootecnia, Viçosa, MG, v. 31, n. 2, p. 1050-1058, 2002. 